\title{
Patients with autosomal dominant spinocerebellar ataxia have more risk of falls, important balance impairment, and decreased ability to function
}

\author{
Pacientes com ataxia espinocerebelar autossômica dominante apresentam \\ maior risco de quedas, déficit de equilíbrio corporal e redução da capacidade funcional \\ Carolina Yuri P. Aizawa, José Luiz Pedroso, Pedro Braga-Neto, Marilia Rezende Callegari, Orlando Graziani \\ Povoas Barsottini
}

\begin{abstract}
Objectives: To assess balance and ability to function in patients with spinocerebellar ataxia. Methods: A total of 44 patients with different spinocerebellar ataxia types 1, 2, 3, and 6 were evaluated using the Tinetti balance and gait assessment and the functional independence measure. The scale for the assessment and rating of ataxia and the international cooperative ataxia rating scale were used to evaluate disease severity. Results: Most patients showed significant risk of falls. The balance scores were significantly different in spinocerebellar ataxia types. A significant positive correlation between balance and disease severity was found. Conclusion: Patients with spinocerebellar ataxia have important balance impairment and risk of falls that influence the ability to function such as self-care, transfers, and locomotion. Furthermore, the more severe ataxia is, the more compromised are postural balance, risk of falls, and ability to function.
\end{abstract}

Key words: spinocerebellar ataxias, postural balance, risk of falls, ability to function.

RESUMO:

Objetivos: Avaliar o equilíbrio e a capacidade funcional em pacientes com ataxia espinocerebelar. Métodos: Quarenta e quatro pacientes com diferentes tipos de ataxia espinocerebelar foram avaliados usando os testes de equilíbrio e de marcha de Tinetti, e da Medida de Independência Funcional. A Escala para Avaliação e Graduação de Ataxia e a Escala Cooperativa Internacional para Graduação de Ataxia foram utilizadas para avaliar a gravidade da doença. Resultados: A maioria dos pacientes apresentou risco significativo de quedas. As pontuações de equilíbrio foram diferentes entre os tipos de ataxia espinocerebelar. Foi encontrada correlação positiva entre o déficit de equilíbrio e a gravidade da doença. Conclusão: Os pacientes com ataxia espinocerebelar possuem comprometimento importante do equilíbrio e risco de quedas, que influenciam a capacidade funcional, como por exemplo: auto-cuidado, transferências e locomoção. Além disso, quanto mais grave a ataxia, maior o comprometimento do equilíbrio postural, do risco de quedas, e da capacidade funcional.

Palavras-Chave: ataxias espinocerebelares, equilíbrio, risco de quedas, capacidade funcional.

Spinocerebellar ataxias (SCA) comprise a group of autosomal dominant neurodegenerative disorders with involvement of the cerebellum and its afferent and efferent pathways ${ }^{1,2}$. Disease onset usually occurs in individuals between the third and fifth decade of life with great variability of clinical presentations ${ }^{3}$. The most common SCA are characterized by expanded CAG trinucleotide that repeats the encode glutamine amino acid, the so-called polyglutamine diseases. So far, more than 30 SCA types have been described.

Balance disturbance in ataxias results in increased postural sway, excessive or reduced response to disturbances, poor balance control during body movements, and unusual body oscillation. It may be a consequence of motor unit recruitment order reversals, delayed recruitment of proximal synergic muscles or coactivation of antagonist muscles, delayed activation of postural responses, inadequate amplitudes of muscle responses, and motor adaptation to tasks and environment. The cerebellum cannot sort out inputs from other systems and balance muscle activities for effective timely contractions and appropriate control of upright standing. Thus, impaired balance and lack of coordination in the lower limbs result in oscillations in the orthostatic position and ataxic gait ${ }^{4,5}$. 
Gait instability and coordination impairment are the main features in patients with SCA. They may lead to significant functional decline in activities of daily living (ADLs) and social activities and increased dependence. However, the impact of these features in each type of SCA is not yet known since they have different phenotypes and clinical presentations.

This study aimed to evaluate static and dynamic balance and ability to function in patients with different types of SCA and to correlate them with ataxia severity and disease duration.

\section{METHODS}

A cross-sectional observational study was performed in a sample of patients with SCA followed up in the Ataxia Unit at Universidade Federal de São Paulo (UNIFESP) in São Paulo, Brazil. All patients signed a free consent form approved by our institutional research board. Patients with clinical and molecular-proven SCA types 1, 2, 3, and 6 were included in the study. Wheelchair patients and those with major cognitive deficit (mini-mental state examination [MMSE] score $<24$ or $<19$ if illiterate $)^{6-8}$ were excluded. SCA7 patients were excluded due to visual impairment.

Forty-six patients with SCA were evaluated: 4 were SCA1; 12 SCA2; 21 SCA3, and 9 SCA6. Their age ranged from 21 to 84 years. One patient with SCA2 and one SCA6 were excluded due to cognitive impairment (MMSE score <24). Thus, a total of 44 patients were evaluated using clinical scales. Of them, 23 were males and 21 females with disease duration ranging from 3 to 28 years.

Balance was assessed using the Tinetti balance and gait assessment. The Tinetti test (TT) consists of two scales with a total score of 28. A score lower than 19 indicates high risk of falls ${ }^{9-12}$. Ability to function was evaluated using the functional independence measure (FIM). The FIM is an 18-item scale that assesses performance in common daily life tasks in six subscales: self-care, sphincter control, transfers, locomotion, communication, and social cognition. This scale's scores range from 18 to 126 , and high scores indicate good functional independence in $\mathrm{ADLs}{ }^{13-15}$.

To assess disease severity, the scale for the assessment and rating ataxia (SARA $)^{16}$ and the international cooperative ataxia rating scale (ICARS) were used. The same researcher (C.Y.P.A.) performed all clinical assessments using the scales mentioned before.

\section{STATISTICAL ANALYSIS}

Normal distribution of data was confirmed using the Kolmogorov-Smirnov test. Comparisons between groups were carried out using Student's $t$-test. Correlations among disease time, SARA, ICARS, and TT were assessed using Pearson's test. ANOVA was used to compare SCA types regarding Tinetti fall risk index and ANOVA with repeated measures was used to compare them regarding the FIM results. A corrected $\mathrm{p}$-value of 0.05 was set for statistical significance.

\section{RESULTS}

Static and dynamic balance, fall risk, and ability to function were impaired in SCA patients. No significant difference was found regarding dynamic balance and Tinetti fall risk index when we compared one SCA type with another. However, significantly different scores were found in the static balance scale $(\mathrm{p}=0.024)$ comparing different SCA types (Table 1). Note that only SCA6 patients showed no risk of falls (Tinetti fall risk index $>19$ ).

Ability to function was assessed through the FIM scale and was significantly impaired in SCA patients (Table 2). No significant difference was found in the ability to function when we compared different SCA types.

A positive correlation was found between balance impairment (static and dynamic balance - Tinetti fall risk Index) and functional disability (FIM scale) ( $\mathrm{r}=0.63$ ) (Figure). It was also found that the subscales related to self-care, transfers, and locomotion were the most affected among all SCA patients.

A negative correlation was found between balance impairment and disease severity measured through the SARA and ICARS scales ( $r=-0.73$ SARA; $r=-0.71$ ICARS). A negative correlation was also found between ability to function and disease severity ( $r=-0.625$ SARA; $r=-0.54$ ICARS) as well as in the FIM subscales related to self-care, transfers, and locomotion.

\section{DISCUSSION}

Our study demonstrated that SCA patients have important static and dynamic balance impairment and higher risk of falls.

Table 1. Comparison between spinocerebellar ataxia types and Tinetti fall risk index scores.

\begin{tabular}{|c|c|c|c|c|c|}
\hline & Tinetti & Average & Median & $\begin{array}{l}\text { Standard } \\
\text { deviation }\end{array}$ & $p$-value \\
\hline \multirow{4}{*}{ Total } & SCA1 & 12.0 & 13 & 3.2 & \multirow{4}{*}{0.074} \\
\hline & SCA2 & 15.0 & 15 & 5.5 & \\
\hline & SCA3 & 15.2 & 16 & 5.6 & \\
\hline & SCA6 & 20.1 & 22 & 5.7 & \\
\hline \multirow{4}{*}{ Balance } & SCA1 & 6.3 & 7 & 2.8 & \multirow{4}{*}{0.024} \\
\hline & SCA2 & 8.2 & 9 & 3.0 & \\
\hline & SCA3 & 9.0 & 9 & 3.2 & \\
\hline & SCA6 & 11.8 & 13 & 3.0 & \\
\hline \multirow{4}{*}{ Gait } & SCA1 & 5.8 & 6 & 0.5 & \multirow{4}{*}{0.301} \\
\hline & SCA2 & 6.8 & 6 & 3.1 & \\
\hline & SCA3 & 6.3 & 6 & 2.8 & \\
\hline & SCA6 & 8.4 & 9 & 2.9 & \\
\hline
\end{tabular}


Table 2. Comparison between functional independence measure subscales for each spinocerebellar ataxia type.

\begin{tabular}{lcccccccc} 
& FIM & Self-care & Sphincter control & Transfers & Locomotion & Communication & Social cognition & $p$-value \\
SCA1 & Average (SD) & $899( \pm 7.1)$ & $94.6( \pm 10.7)$ & $88.1( \pm 4.8)$ & $71.4( \pm 13.0)$ & $100( \pm 0.0)$ & $94.0( \pm 11.9)$ & 0.013 \\
SCA2 & Average (SD) & $89.8( \pm 8.0)$ & $98.1( \pm 6.5)$ & $87.0( \pm 8.5)$ & $75.3( \pm 19.8)$ & $100( \pm 0.0)$ & $94.8( \pm 6.5)$ & 0.020 \\
SCA3 & Average (SD) & $90.7( \pm 10.0)$ & $91.2( \pm 15.0)$ & $88.4( \pm 10.6)$ & $79.9( \pm 14.0)$ & $100( \pm 0.0)$ & $96.6( \pm 6.2)$ & $<0.001$ \\
SCA6 & Average (SD) & $94.6( \pm 5.2)$ & $92.0( \pm 11.1)$ & $91.7( \pm 5.5)$ & $81.3( \pm 18.7)$ & $100( \pm 0.0)$ & $92.3( \pm 13.2)$ & 0.003 \\
\hline
\end{tabular}

SD: standard deviation, values in \%.

Tinetti and FIM Correlation - Total Sample
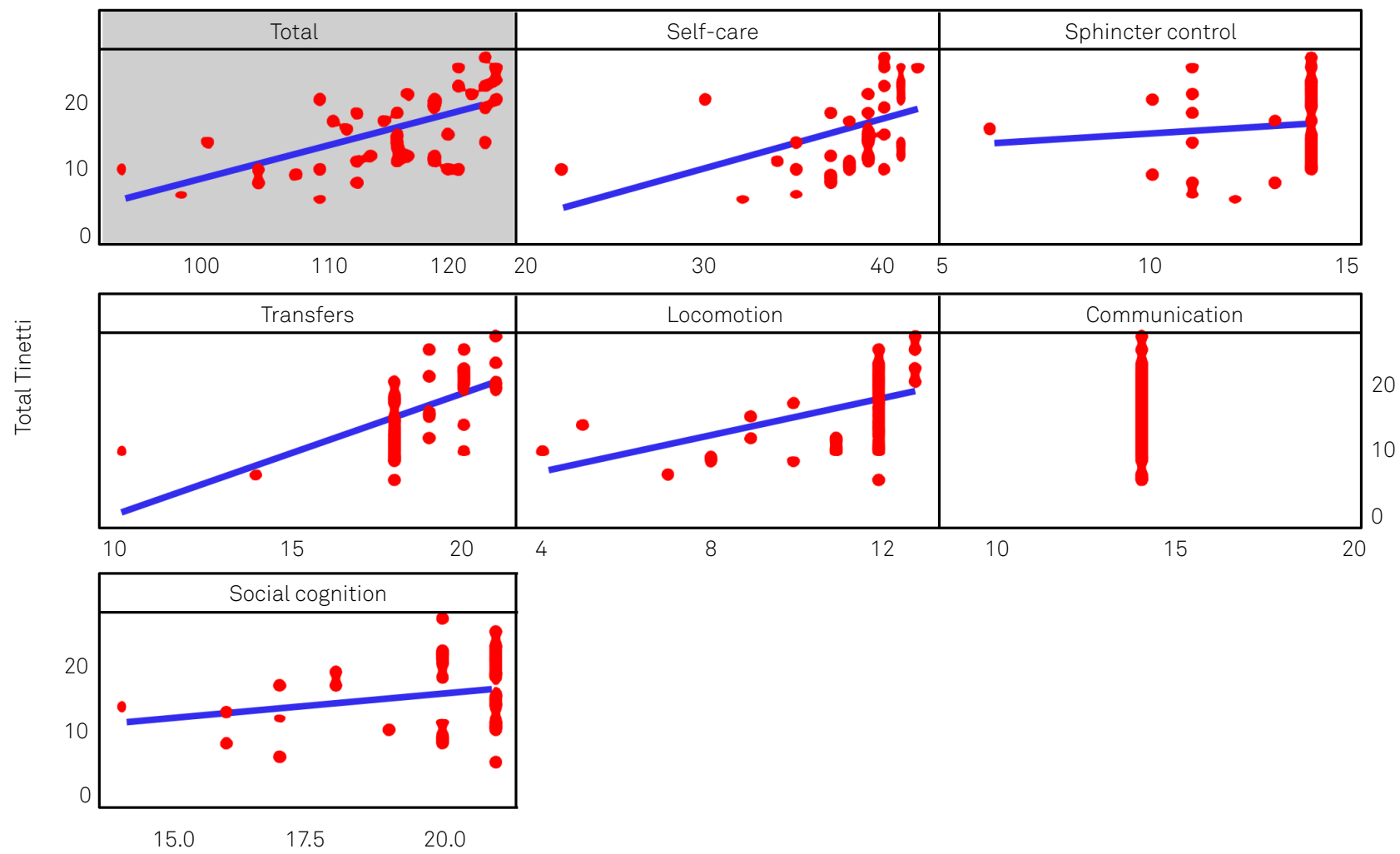

Figure. Correlation between total Tinetti and functional independence measure scores in all spinocerebellar ataxia patients.

These features have a direct impact on their ability to function including self-care, transfers, and locomotion. Additionally, there was a clear positive correlation between balance impairment and functional disability and disease severity. Conversely, no correlation was found between balance impairment and disability and disease duration, except for SCA2 patients. This study also showed that functional disability and dynamic balance are not affected by the SCA type, but patients with different SCA types showed varying degrees of static balance impairment.

According to previous data and based on our personal clinical experience, the most common symptom in SCA patients are balance problems and gait disturbances leading to impaired daily functions and locomotion",17,18. In 2009, Leonardi et $\mathrm{al}^{17}$. showed a positive correlation between balance impairment and risk of falls in seven patients with SCA evidencing through clinical scales that ataxic gait and lack of coordination may lead to static and dynamic imbalance and higher propensity to falls. This is in line with our findings; we demonstrated through clinical scales that patients with SCA have significant balance impairment and higher risk of falls. Interestingly, higher risk of falls was not evidenced in SCA6 patients, probably because they present a pure presentation with late onset of symptoms.

It must be borne in mind that each SCA type has different neurological signs and symptoms associated with ataxia for instance, neuropathy and ophthalmoparesis in SCA2 and SCA3, pyramidal signs in SCA1, and dystonia, and other extrapyramidal signs in SCA3 ${ }^{19-22}$. Therefore, we hypothesized that there will be differences in balance impairment and ability to function in different SCA types. Consistent with that, significantly different degrees of balance impairment were found among SCA types. We can assume that other signs and symptoms other than ataxia may have a great impact on balance, and that patients with SCA1 showed the worst performance. 
Regarding the assessment of ability to function (FIM scale) in these patients, most showed functional scores (FIM $\geq 104$ ) and modified independence. In other words, they had difficulty to perform some daily tasks. A comparison of the subscales in SCA patients showed different performance and ability to function in specific subscales. The patients showed greater difficulty and dependence in the subscales of self-care, transfers, and locomotion correlated to FIM motor scores ${ }^{13}$, which are directly related to balance. A comparison of ability to function between different SCA types found no differences in all FIM scales, suggesting that all patients regardless of the SCA type have similar difficulty in performing ADLs.

Moreover, a positive correlation between balance impairment and ability to function was found in the entire sample and in all SCA types, except for SCA1 patients. This analysis also showed that the subscales related to self-care, transfers, and locomotion are the most affected in these patients and are the most strongly correlated with balance impairment. Therefore, balance impairment had a direct impact on performance of these three tasks, which is consistent with the main complaints reported by these patients in clinical practice.

Our study failed to demonstrate a correlation between disease duration and balance impairment and functional disability. On the other hand, we found a clear correla- tion between ataxia severity and balance impairment and functional disability and offered strong evidence that these two skills are affected by age in SCA patients.

There are some limitations in our study. First, noncerebellar signs including spasticity, neuropathy, and extrapyramidal signs were not assessed and an accurate measure of their impact on balance and gait of patients was not possible. Furthermore, our group of SCA patients was heterogeneous, since only four patients with SCA1 were evaluated compared with 21 patients with SCA3. This may explain some different findings in patients with SCAl compared with the total sample.

In conclusion, this study demonstrated that SCA patients have significant static and dynamic balance impairment and higher risk of falls that have a direct impact on their ability to function, especially regarding self-care, transfers, and locomotion. Also, balance and ability to function were influenced by ataxia severity, and functional disability increases with age in SCA patients. As for each SCA type, there were different degrees of balance impairment. Further studies in SCA patients are necessary to better understand the clinical features that may have an impact on balance and ability to function. This knowledge may be valuable for future planning rehabilitation and physical therapy interventions.

\section{References}

1. Schöls L, Bauer P, Schimidt T, et al. Autosomal dominant cerebellar ataxias: clinical features, genetics, and pathogenesis. Lancet Neurol 2004;3:291-304

2. Trujillo-Martín M Mar, Serrano-Aguilar P, Monton-Álvarez F, et al. Effectiveness and safety of treatments for degenerative ataxias: a systematic review. Mov Disord 2009;24:1111-1124.

3. Braga-Neto P, Neto DS, Pedroso JL, et al. Ataxias hereditárias. In: BertolucciPHF,FerrazHB,FélixEPV,PedrosoJL(Eds). Neurologia-Guias de Medicina Ambulatorial e Hospitalar da UNIFESP-EPM. $1^{\text {a }}$ Ed. São Paulo: Manole, 2010:769-780.

4. Dias LM, Toti F, Almeida SEM, et al. Efeito do peso para membros inferiores no equilíbrio estático e dinâmico nos portadores de ataxia. Acta Fisiatr 2009;16:116-120.

5. Shumway-cook, Woolacott MH. Controle motor: teoria e aplicações práticas. $2^{a}$ ed. Barueri: Manole, 2003.

6. Almeida OP. Mini Exame do Estado Mental e o diagnóstico de demência no Brasil. Arq Neuropsiquiatr 1998;56:605-612.

7. Mutarelli EG. Propedêutica neurológica: do sintoma ao diagnóstico. São Paulo: Sarvier; 2000.

8. Kochhann R, Varela JS, Lisboa CSM, et al. The mini mental state examination - Review of cutoff points adjusted for schooling in a large Southern Brazilian sample. Dement Neuropsychol 2010; 4:35-41.

9. Araújo MJL, Cardoso PL, Silva LC, et al. A atuação da fisioterapia neurofuncional na doença de José-Machado: relato de caso. Neurobiologia 2010;73:75-84.

10. Kauffman TL. Manual de reabilitação geriátrica. Rio de Janeiro: Guanabara Koogan, 2001.

11. Freitas EV, Miranda RD, Nery MR. Parâmetros clínicos do envelhecimento e avaliação geriátrica global. In: Freita EV, Py L, Cançado FAX, Doll J, Gorzoni ML. Tratado de geriatria e gerontologia. Rio de Janeiro, RJ: Guanabara Koogan, 2002:609-617.
12. Carvalho GA, Peixoto NM, Capella PD. Análise comparativa da avaliação funcionaldopacientegeriátricoinstitucionalizadopormeiodosprotocolos de Katz e Tinetti. www.efdeportes.com/ Rev Dig (Buenos Aires) 2007.

13. Riberto M, Miyazaki M, Filho DJ, et al. Reprodutibilidade da versão brasileira da Medida de Independência Funcional. Acta Fisiátrica 2001;8(1):45-52, 2001.

14. Riberto M, Miyazaki M, Jucá SSH, et al. Validação da Versão Brasileira da Medida de Independência Funcional. Acta Fisiátrica 2004;11:72-76.

15. Riberto M, Pinto PPN, Sakamoto H, et al. Independência funcional de pacientes com lesão medular. Acta Fisiatr 2005;12:61-66.

16. Braga-Neto P, Junior CG, Dutra LA, et al. Translation and validation into Brazilian version of the Scale of the Assessment and Rating of Ataxia (SARA). Arq Neuropsiquiatr 2010;68:228-230.

17. Leonardi MM, Lopes GJ, Bezerra PP, et al. Impacto do desequilibrio estático e dinâmico no risco de quedas em indivíduos com ataxia espinocerebelar. Rev Neurocienc 2009;17:178-182.

18. Oliveira AP, Freitas AM. Efeitos da avaliação fisioterapêutica nas habilidades funcionais e no equilíbrio de um paciente com ataxia espinocerebelar: estudo de caso. Fisio Pesq 2006;13:53-59.

19. Pedroso JL, Bezerra ML, Braga-Neto P, et al. Is neuropathy involved with restless legs syndrome in Machado-Joseph disease? Eur Neurol 2011;66:200-203.

20. Pedroso JL, Braga-Neto P, Felício AC, et al. Akathisia: an unusual movement disorder in Machado-Joseph disease. Parkinsonism Relat Disord 2011;17:712-713.

21. Pedroso JL, Braga-Neto P, Felício AC, et al. Sleep disorders in Machado-Joseph disease: frequency, discriminative thresholds, predictive values, and correlation with ataxia-related motor and non-motor features. Cerebellum 2011;10:291-295.

22. Braga-Neto P, Pedroso JL, Alessi H, et al. Cerebellar cognitive affective syndrome in Machado Joseph disease: core clinical features. Cerebellum 2012;11:549-556. 